\title{
Aplikasi Lakase pada Proses Refining Pulp
}

\author{
Hendro Risdianto, Sonny Kurnia Wirawan, Susi Sugesty \\ Balai Besar Pulp dan Kertas, Jl. Raya Dayeuhkolot No. 132, Bandung, Indonesia
}

Diterima : 2 Juli 2019, Revisi akhir : 23 Desember 2019, Disetujui terbit : 30 Desember 2019

\section{Laccase Application in Pulp Refining Process}

\begin{abstract}
Refining is a process to modify fibers with the aim of increasing fiber bonds and developing paper strength. The research that has been done includes determining the refining conditions with PFIMill and determining the conditions of pretreatment of laccase which will then be applied to the biorefining process. The PFI mill revolutions of 2500 is the optimum to produce the strength of the Acacia crassicarpa pulp. Whereas the results of the study showed that optimum laccase conditions showed that laccase had the highest reaction rate $(0.0018 \mathrm{mM} / \mathrm{s})$ at $50^{\circ} \mathrm{C}$. In the refining process, the initial freeness of the pulp is around $550 \mathrm{mLCSF}$, and when subjected to laccase treatment it drops to 515 (LMS1) and 520 (LMS2). Refining the pulp without enzyme treatment produced tensile, bursting and tearing indexes of $6.4 .10^{-2} \mathrm{kNm} / \mathrm{g}, 5.18 \mathrm{kPa} . \mathrm{m}^{2} / \mathrm{g}$, and $5.96 \mathrm{mN.} \mathrm{m}^{2} / \mathrm{g}$, respectively. The tear index did not change significantly in all treatments. The LMS1 treatment increased the tensile index to $6.83 \mathrm{kNm} / \mathrm{g}$ and the tear index to $7.53 \mathrm{mN.m} / \mathrm{g}$. The tensile and tear index in LMS2 decreased compared to LMS1, but it was still higher than without treatment. Thus, laccase treatment in the refining process can increase the tensile index and tear index of the sheet.
\end{abstract}

Keywords: refining, laccase, Acacia crassicarpa, freeness

\begin{abstract}
Abstrak
Refining merupakan proses untuk memodifikasi serat dengan tujuan meningkatkan ikatan serat dan mengembangkan kekuatan kertas. Penelitian yang telah dilakukan meliputi penentuan kondisi refining dengan PFI Mill dan penentuan kondisi perlakuan awal lakase yang selanjutnya akan diterapkan pada proses biorefining. Jumlah putaran 2500 dari PFI mill merupakan jumlah yang optimum untuk menghasilkan kekuatan pulp Acacia crassicarpa. Sedangkan hasil penelitian kondisi optimum lakase menunjukkan bahwa lakase memiliki laju reaksi yang paling tinggi $(0,0018 \mathrm{mM} / \mathrm{s})$ pada suhu $50^{\circ} \mathrm{C}$. Pada proses refining, freeness awal pulp adalah sekitar $550 \mathrm{~mL}$ CSF, dan ketika dikenakan perlakuan lakase turun menjadi 515 (LMS1) dan 520 (LMS2). Refining pulp tanpa perlakuan enzim menghasilkan indeks tarik, retak dan sobek berturut-turut adalah $6,4 \cdot 10^{-2} \mathrm{kNm} / \mathrm{g}, 5,18 \mathrm{kPa} \cdot \mathrm{m}^{2} / \mathrm{g}$, dan $5,96 \mathrm{mN} \cdot \mathrm{m}^{2} / \mathrm{g}$. Indeks sobek tidak mengalami perubahan signifikan pada semua perlakuan. Perlakuan LMS1 meningkatkan indeks tarik menjadi $6,83 \mathrm{kNm} / \mathrm{g}$ dan indeks sobek menjadi $7,53 \mathrm{mN} . \mathrm{m}^{2} / \mathrm{g}$. Indeks tarik dan sobek pada LMS2 menurun dibandingkan LMS1, namun masih lebih tinggi dibandingkan tanpa perlakuan. Dengan demikian perlakuan lakase pada proses refining dapat meningkatkan indeks tarik dan indeks sobek lembaran.
\end{abstract}

Kata kunci: refining, lakase, Acacia crassicarpa, freeness 


\section{Pendahuluan}

Pulp belum putih Acacia crassicarpa merupakan salah satu pulp kayu daun yang sedang dikembangkan sebagai bahan baku kertas (Sugesty, Kardiansyah andPratiwi, 2015). Acacia crassicarpa memiliki nama lain yaitu thickpodded salwood, red wattle, Papua New Guinea red wattle, northern wattle, brown salwood. Tanaman ini merupakan spesies cepat tumbuh. A. crassicarpa dapat mencapai ketinggian $25-30 \mathrm{~m}$, dengan diameter batang $50-60 \mathrm{~cm}$. Spesies berasal dari Australia, Indonesia dan Papua New Guinea, dan tersebar sampai ke wilayah China, Fiji, Malaysia, Tanzania, Thailand. Acacia crassicarpa cocok digunakan sebagai bahan bakar, serat dan kayu. Sebagai bahan bakar, spesies ini dapat digunakan sebagai kayu bakar dan arang karena memiliki sifat cepat mengering dengan kandungan energi $22.600 \mathrm{~kJ} / \mathrm{kg}$. A. crassicarpa memiliki densitas $670-710 \mathrm{~kg} / \mathrm{m}^{3}$ dan cocok digunakan untuk kayu gergajian seperti untuk konstruksi, furniture, lantai kayu, dan papan. Kayu ini juga cocok untuk sumber pulp dengan rendemen tersaring $47 \%$ pada pemasakan kraft dengan produktivitas $300 \mathrm{~kg} / \mathrm{m}^{3}$ (Orwa et al., 2009).

Pada proses pembuatan pulp dan kertas, refining merupakan proses untuk memodifikasi serat dengan tujuan meningkatkan ikatan serat dan mengembangkan kekuatan kertas. Karena pentingnya proses ini maka proses refining merupakan jantung proses pembuatan kertas. Namun, proses refining merupakan proses dengan tingkat energi yang tinggi (Gharehkhani et al., 2015). Saat ini, tuntutan untuk hemat energi dan peraturan lingkungan menyebabkan industri kertas untuk menerapkan strategi menurunkan konsumsi energi, salah satunya di unit refining. Langkah-langkah yang dapat diterapkan antara lain modifikasi pola pisau refiner, konsistensi stok, pola aliran, dan desain ulang refiner. Akan tetapi, langkah-langkah tersebut memerlukan investasi yang tinggi, sehingga perlu menggunakan metode yang mudah dan sederhana. Enzim merupakan salah satu alternatif yang baik untuk mengatasi hal tersebut.

Pada proses refining, terutama untuk pulp belum putih, lignin sangat berpengaruh terhadap hasil karena sifatnya yang hidrofob. Air membantu proses pengembangan serat selama refining. Lakase dengan kemampuannya mendegradasi lignin dapat membantu untuk proses penyerapan air yang akhirnya dapat membantu proses refining menghasilkan fibrilasi eksternal. Lecourt, Soranzo and PetitConil (2011) telah menggunakan lakase dengan bantuan mediator sebagai perlakuan awal proses refining pulp belum putih Pinus radiata. Hasil perlakuan lakase mampu meningkatkan kualitas pulp untuk panjang putus dan kekuatan tarik. Proses refining dengan perlakuan lakase dapat menurunkan energi sebesar $36 \%$.

Lakase tidak mampu untuk mendegradasi lignin secara langsung karena ukurannya yang besar. Oleh karena itu, diperlukan mediator dalam proses kimia atau biologi reaksi yang melibatkan lakase (Hamidi, 2013). Salah satu mediator yang dapat digunakan adalah Hydroxybenzotriazole (HBT). Penggunaan mediator juga berhubungan dengan kemampuan lakase yang hanya dapat mendegradasi gugus fenol lignin tanpa adanya mediator. Penambahan mediator mampu memperluas degradasi gugus non fenol lignin (Hilgers et al., 2018). Penelitian ini bertujuan untuk menentukan kondisi proses refining pulp belum putih Acacia crassicarpa menggunakan lakase sehingga diharapkan mampu menurunkan freeness awal dan kebutuhan energi refining.

\section{Bahan dan Metode}

\section{Pembuatan Pulp}

Bahan baku pembuatan pulp dan kondisi pembuatan pulp yang dijelaskan oleh Sugesty, Kardiansyah and Pratiwi (2015). Acacica crassicarpa umur 4 tahun dibuat menjadi bentuk serpih dengan ukuran $3 \times 3 \times 0,5 \mathrm{~cm}^{3}$ kemudian dimasak mengunakan proses kraft dengan kondisi disajikan pada Tabel 1.

Tabel 1. Pemasakan Acacia crassicarpa

\begin{tabular}{lc}
\hline Parameter & Kondisi Pemasakan \\
\hline Suhu, ${ }^{\circ} \mathrm{C}$ & 165 \\
Rasio larutan pemasak & $4: 1$ \\
terhadap kayu & \\
Sulfiditas, \% & $30 \%$ \\
Alkali aktif, \% & 20 \\
Waktu, jam & $2+1,5$ \\
\hline
\end{tabular}




\section{Refining Pulp Belum Putih menggunakan PFI Mill}

Proses refining dilakukan untuk pulp belum putih hasil proses pemasakan menggunakan PFI mill. Refining pada pulp kontrol (tanpa perlakuan lakase) dilakukan pada 0 - 3.500 putaran. Jumlah putaran optimum yang diperoleh digunakan untuk proses refining untuk pulp dengan perlakuan lakase. Proses refining dilakukan sesuai dengan SNI ISO 5264-2:2011 - Pulp - Penggilingan di laboratorium - bagian 2: metode PFI mill. Analisis pulp hasil refining adalah freeness, ketahanan tarik, ketahanan sobek dan energi. Freeness ditentukan berdasarkan SNI ISO 52672:2010 - Pulp - Cara uji kemampuan drainaseBagian 2: Metode Canadian Standard Freeness (CSF), Ketahanan tarik ditentukan berdasarkan SNI ISO 1924-2:2010 Kertas dan karton - Cara uji sifat tarik-Bagian 2: Metode kecepatan elongasi tetap $(20 \mathrm{~mm} / \mathrm{min})$. Ketahanan sobek ditentukan berdasarkan SNI ISO 1974:2016 Kertas - Cara uji ketahanan sobek - Metode Elmendorf. Energi refining dapat dibaca dari PFI mill dalam satuan Wh.

\section{Penentuan Kondisi Optimum Penggunaan Lakase}

Kondisi optimum lakase untuk refining ditentukan dengan mereaksikan lakase dengan senyawa aromatik dengan berat molekul besar mirip dengan lignin yaitu ABTS (2,2'-Azinobis[3-Ethylbenzothiazoline- 6-Sulfonic Acid]).

\section{Enzim, Substrat dan Larutan Penyangga}

Enzim yang digunakan adalah lakase dari Trametes versicolor diperoleh dari Sigma Aldrich. Substrat untuk reaksi enzimatis adalah ABTS yang diproleh dari Sigma Aldrich. Lakase sebanyak 0,01 gram dan dimasukkan ke dalam labu ukur $10 \mathrm{~mL}$ diencerkan sampai tanda tera dengan akuades. Larutan enzim dipipet ke dalam tube scale 0,5 $\mathrm{mL}$ dan dijadikan menjadi 20 tabung dan selanjutnya dilakukan pengenceran 4 kali. ABTS ditimbang sebanyak 0,0550 gram kemudian dibuat variasi konsentrasi yaitu $0,1 \mathrm{mM}$, $0.5 \mathrm{mM}, 0,8 \mathrm{mM}, 1 \mathrm{mM}, 1,5 \mathrm{mM}$, dan $2 \mathrm{mM}$. Larutan penyangga asetat yang digunakan memiliki $\mathrm{pH}$ 4,6.

\section{Penentuan Kinetika Lakase}

Reaksi enzimatis dilakukan dalam kuvet pada suhu kamar yang terdiri atas $900 \mu \mathrm{L}$ larutan penyangga asetat $10 \mu \mathrm{L}$ lakase dan $100 \mu \mathrm{L}$ ABTS dengan variasi $0,1 \mathrm{mM}, 0,5 \mathrm{mM}, 0,8 \mathrm{mM}$, $1 \mathrm{mM}, 1,5 \mathrm{mM}$, dan $2 \mathrm{mM}$ ). Setiap 5 menit diamati nilai absorbansi pada panjang gelombang $420 \mathrm{~nm}$ selama 120 menit menggunakan spektrofotometer Genesys 20. Aktivitas lakase ditentukan berdasarkan Risdianto et al. (2012).

Penentuan kinetika reaksi lakase ditentukan dengan mengukur aktivitas lakase pada berbagai konsentrasisubstrat.Parameterkinetikaditentukan dengan menginkubasikan enzim dengan berbagai variasi substrat dan suhu. Selanjutnya, nilai konstanta Michaelis-Menten $\left(K_{m}\right)$ dan kecepatan maksimum $\left(V_{\text {maks }}\right)$ dapat ditetapkan dengan menggunakan beberapa persamaan seperti persamaan Lineweaver-Burk (1), Hanes-Woolf (2) dan Eadie-Hofstee (3).

$\frac{1}{V}=\frac{K m}{V m a k s} \frac{1}{[S]}+\frac{1}{V}$

$\frac{[S]}{V}=\frac{1}{V m a k s}[\mathrm{~S}]+\frac{\mathrm{Km}}{V \text { maks }}$

$V=-\frac{K m V}{[S]}+\mathrm{Vmaks}$

\section{Penentuan Suhu Optimum}

Perlakuan lakase dengan ABTS seperti dijelaskan pada penentuan kinetika lakase namun dengan variasi suhu $30-70^{\circ} \mathrm{C}$.

\section{Perlakuan Lakase}

Perlakuan lakase dilakukan sebelum proses refining menggunakan PFI mill. Perlakuan dengan lakase komersial (Laccase from Trametes versicolor) menggunakan mediator HBT (1-hydroxybenzotriazole). Kondisi perlakuan dengan enzim adalah lakase komersial $1 \mathrm{~g} / \mathrm{L}$, HBT $0,05 \mathrm{M}$, konsistensi $3 \%$, suhu $50^{\circ} \mathrm{C}$, waktu 4 jam dan putaran pengaduk $200 \mathrm{rpm}$. Variasi yang digunakan adalah LMS1 (volume lakase $10 \mathrm{~mL}$ ) dan LMS2 (volume lakase $30 \mathrm{~mL}$ ). Suspensi ditambahkan larutan penyangga asetat sehingga menghasilkan konsistensi 3\%. 


\section{Hasil dan Pembahasan}

\section{Pembuatan Pulp}

Komponen kimia Acacia crassicarpa disajikan pada Tabel 2. Selulosa, hemiselulosa dan lignin merupakan komponen utama penyusun Acacia crassicarpa dengan kadar seperti disajikan pada Tabel 2. Kayu ini cocok untuk dibuat pulp karena memiliki kadar selulosa lebih dari 40\% (AbdulKhalil, Siti Alwani and Mohd Omar, 2006). Penelitian ini memanfaatkan hasil penelitian Sugesty, Kardiansyah and Pratiwi, (2015) yang menyatakan bahwa kayu dari Acacia crassicarpa umur 4 tahun dapat dibuat untuk pulp dan kertas.

Berdasarkan ukuran dimensi dan turunannya (Tabel 3), serat Acacia crassicarpa memiliki panjang serat yang termasuk dalam golongan menengah sampai sedang (Sugesty, Kardiansyah and Pratiwi, 2015). Menurut peneliti lain berdasarkan panjang, serat dikelompokkan menjadi 3. Kelompok pertama adalah serat dengan panjang kurang dari $0,9 \mathrm{~mm}$, kelompok kedua adalah serat dengan panjang antara $0,9-1,9 \mathrm{~mm}$ dan kelompok ketiga adalah serat dengan panjang lebih dari $1,9 \mathrm{~mm}$ (Khakifirooz et al., 2013). Dengan demikian, serat Acacia crassicarpa termasuk kelompok kedua. Nilai kelangsingan Acacia crassicarpa $(55,41)$ lebih rendah dibandingkan kayu jarum $(95-120)$ (Ververis et al., 2004). Nilai kelangsingan yang baik untuk pembuatan pulp dan kertas adalah di atas 33 (Kiaei, 2014). Panjang serat dan nilai kelangsingan tinggi akan menghasilkan pulp dengan kekuatan sobek yang tinggi. Acacia

Tabel 2. Komponen Kimia Acacia crassicarpa

\begin{tabular}{clc}
\hline No & Parameter & Kadar, \% \\
\hline 1 & Air & 10,63 \\
2 & Abu & 0,78 \\
3 & Pentosan & 19 \\
4 & Sari & 1,89 \\
5 & Lignin & 29,31 \\
6 & Holoselulosa & 76,95 \\
7 & a selulosa & 46,28 \\
8 & Kelarutan dalam NaOH 1\% & 16,67 \\
9 & Kelarutan dalam air panas & 1,65 \\
10 & Kelarutan dalam air dingin & 1,46 \\
\hline
\end{tabular}

crassicarpa memiliki bilangan Runkel 0,42 yang berarti mudah untuk digiling (refining). Nilai standarbilanganRunkelagarmudahdigilingadalah kurang dari 1 (Udohitinah and Oluwadare, 2011). Fleksibilitas Acacia crassicarpa adalah $71 \%$, yang menandakan bahwa serat Acacia crassicarpa bersifat elastis. Serat yang elastis memiliki nilai fleksibilitas antara 50-75\% (Kiaei, 2014). Oleh karena itu, berdasarkan bilangan Runkel dan fleksibilitas maka serat Acacia crassicarpa ini akan sesuai untuk proses refining pada pembuatan pulp.

Pada proses pemasakan menggunakan kondisi seperti disajikan pada Tabel $\mathbf{1}$ menghasilkan Bilangan Kappa 15,01. Nilai ini sejalan dengan hasil penelitian Sugesty, Kardiansyah and Pratiwi, (2015). Nilai tersebut mengindikasikan bahwa pulp yang dihasilkan mampu untuk diputihkan dan derajat cerah yang dihasilkan dapat tercapai.

\section{Penentuan Putaran Optimum PFI Mill untuk Proses Refining}

Gambar 1 menyajikan freeness pulp pada berbagai jumlah putaran PFI mill. Freeness pulp $A$. crassicarpa menurun seiring dengan bertambahnya putaran PFI mill. Penurunan freeness ini sesuai dengan penelitian Masrol et al. (2015) yang telah melakukan refining pada pulp Oil Palm Male Flower Spikes Fibre dengan PFI mill pada jumlah putaran 0 sampai dengan 3000. Lembaran pulp yang dihasilkan dikarakteristik ketahanan tarik, ketahanan sobek dan brightness. Semakin turun nilai freeness, menunjukkan terjadinya proses fibrilasi yang menyebabkan ketahanan

Tabel 3. Morfologi Serat Acacia crassicarpa

\begin{tabular}{clc}
\hline No & Parameter & Nilai \\
\hline 1 & Panjang serat,rata-rata $(\mathrm{mm})$ & 1,51 \\
2 & Diameter luar $(\mu \mathrm{m})$ & 27,19 \\
3 & Diameter dalam $(\mu \mathrm{m})$ & 19,18 \\
4 & Tebal dinding $(\mu \mathrm{m})$ & 4,01 \\
5 & Bilangan runkel & 0,42 \\
6 & Kelangsingan & 55,41 \\
7 & Kekakuan & 0,15 \\
8 & Kelenturan & 0,71 \\
9 & Muhlstep ratio $(\%)$ & 50,25 \\
\hline
\end{tabular}


tarik meningkat sampai titik optimum kemudian menurun, penurunan ini disebabkan karena pemendekan serat seperti ditunjukkan oleh Gambar 3 (Chauhan et al., 2011). Demikian halnya yang terjadi pada ketahanan sobek (Gambar 4). Rushdan (2003) menyimpulkan kondisi ini disebabkan oleh peningkatan tingkat pembasahan pulp, pemendekan serat dan produksi fines. Fines sangat mengurangi drainase air dalam formasi kertas dengan mengisi pori-pori di lembaran, tetapi pada saat yang sama memberikan lebih banyak area kontak serat - serat karena adanya fibrilasi (Mossello et al., 2010). Peningkatan putaran pada PFI mill atau kenaikan freeness menyebabkan penurunan nilai derajat cerah (Gambar 5). Lian, You and Lian (2012) juga mengemukakan bahwa nilai brightness menurun dari 38,3 menjadi 37,1 selama proses dalam PFI mill pada kenaikan jumlah putaran. Kebutuhan energi untuk menghasilkan fibrilasi juga meningkat seiring dengan

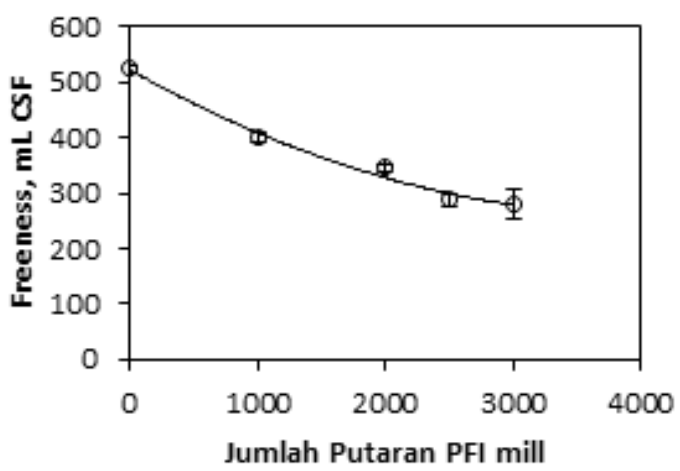

Gambar 1. Freeness yang dihasilkan berdasarkan Putaran PFI Mill.

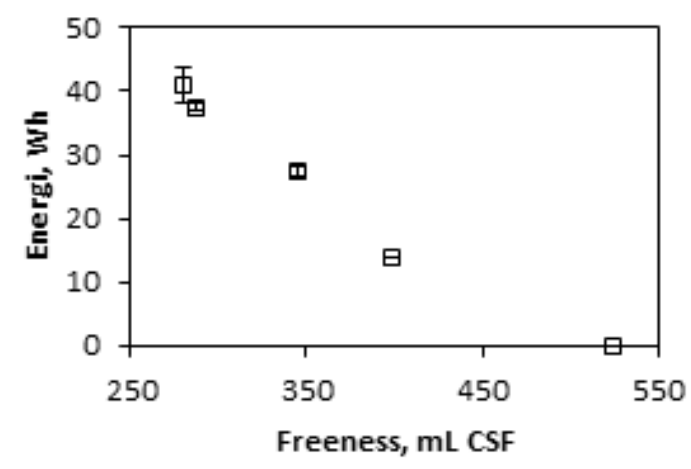

Gambar 2. Energi yang diperlukan Selama Refining menurunnya nilai freeness seperti disajikan pada Gambar 2. Sedangkan pada brightness (derajat cerah), peningkatan jumlah putaran refining atau penurunan freeness menyebabkan penurunan nilai derajat cerah. Menurut Iakovlev, Hiltunen and Van Heiningen, (2010) light scattering coefficient menurun selama

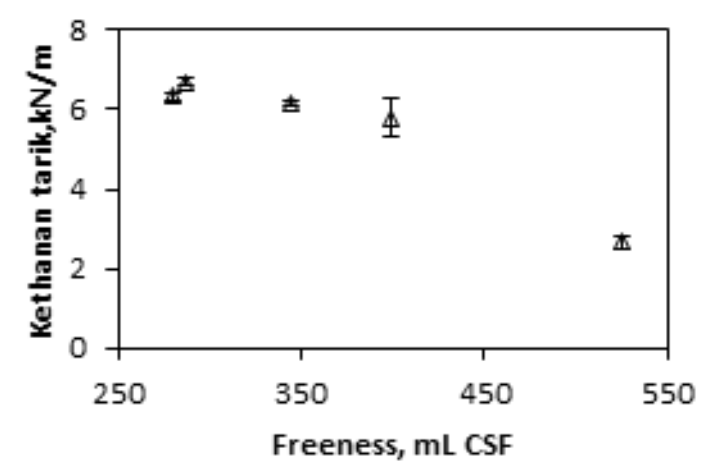

Gambar 3. Ketahanan Tarik selama Proses Refining

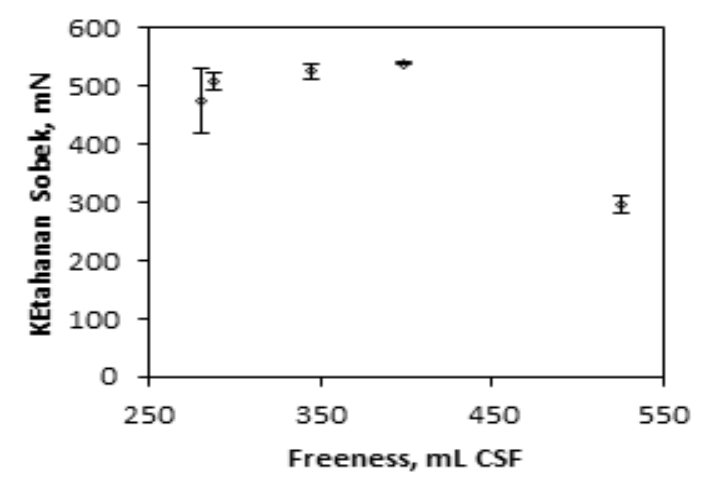

Gambar 4. Ketahanan Sobek selama Proses Refining

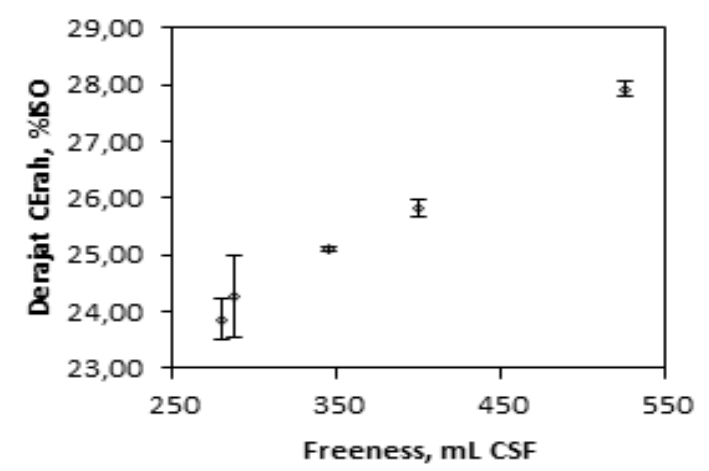

Gambar 5. Derajat Cerah selama Proses Refining 
refining menyebabkan menurunnya derajat cerah. Lian, You and Lian, (2012) menyatakan bahwa penurunan derajat cerah terjadi saat meningkatkan jumlah putaran PFI mill pada refining pulp jerami gandum. Berdasarkan nilai freeness dan karakteristik pulp maka jumlah putaran 2500 dipilih untuk proses refining dengan perlakuan lakase.

\section{Penentuan Kondisi Optimum Lakase untuk Refining}

Sebelum dilakukan refining dengan lakase, perlu ditentukan dosis lakase yang tepat untuk proses refining melalui reaksi enzimatis. Reaksi melibatkan lakase dan substrat dengan model lignin berupa subsrat aromatic dengan berat molekul tinggi yaitu ABTS. Penentuan nilai $K_{m}$ dan $V_{\text {maks }}$ diperlukan untuk mengetahui kinetika reaksi dari suatu enzim, dan bermanfaat sebagai informasi dasar terhadap penggunaan enzim tersebut. Nilai $K_{m}$ dan $V_{\text {maks }}$ dari suatu enzim dapat diketahui berdasarkan aktivitas suatu enzim pada variasi konsentrasi substrat yang berbeda yakni $0,1 \mathrm{mM}-1 \mathrm{mM}$ yang berfungsi untuk pembuatan kurva Michaelis-Menten (Gomes et al., 2009). Hubungan antara konsentrasi substrat dengan kecepatan reaksi atau aktivitas enzim digambarkan pada kurva Michaelis-Menten (Gambar 6).

Tabel 4. Nilai $K_{m}$ dan $V_{\text {maks }}$

\begin{tabular}{lcc}
\hline Metode & $K_{m}$ & $V_{\text {maks }}(\mathrm{mM} / \mathrm{min})$ \\
\hline Lineweaver-Burk & 0,2133 & 0,0013 \\
Eadie-Hofstee & 0,2141 & 0,0013 \\
Hanes-Woolf & 0,2069 & 0,0013 \\
\hline
\end{tabular}

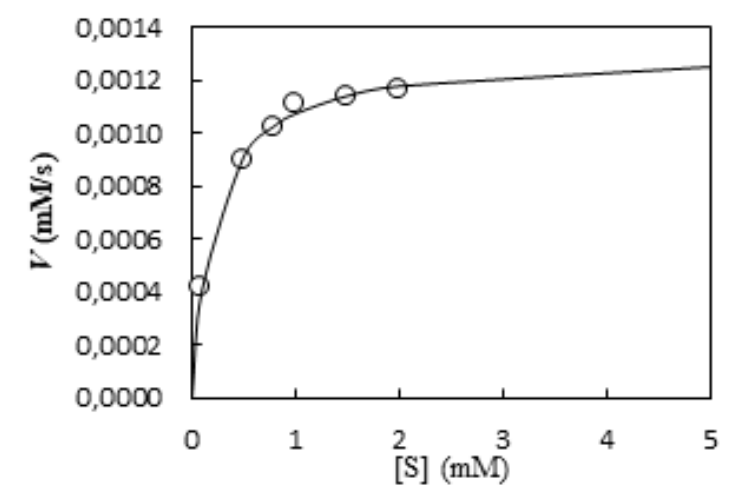

Gambar 6. Kurva Michaelis-Menten
Peningkatan aktivitas lakase belum murni terjadi secara linear dari konsentrasi $0,1 \mathrm{mM}$ sampai dengan $1 \mathrm{mM}$. Hal ini dijelaskan melalui teori kinetika bahwa semakin tinggi konsentrasi substrat maka energi dan frekuensi benturan juga akan semakin tinggi (Asih, 2016) sehingga kompleks antara enzim dengan substrat dalam membentuk kompleks akan semakin banyak (Saropah, Jannah and Maunatin, 2012). Nilai $\mathrm{K}_{\mathrm{m}}$ dan $\mathrm{V}_{\text {maks }}$, ditentukan melalui beberapa pendekatan yakni persamaan Lineweaver-Burk, Eadie-Hofstee, dan Hanes-Woolf seperti disajikan pada Tabel 4.

Aktivitas lakase meningkat saat suhu dinaikkan sampai mencapai maksimal dan kemudian menurun seperti disajikan pada Gambar 7. Suhu optimum reaksi enzimatis lakase adalah $50^{\circ} \mathrm{C}$. Kenaikan suhu di atas suhu optimum reaksi enzimatis akan menyebabkan denaturasi enzim sehingga kecepatan reaksinya menurun. Suhu yang lebih tinggi (di atas $50^{\circ} \mathrm{C}$ ) menunjukkan inaktivasi lakase karena denaturasi protein sehingga enzim kehilangan kapasitas katalitik (Tavares et al., 2015). Hal ini sejalan dengan hasil penelitian yang menyatakan bahwa aktivitas optimum lakase berada pada kisaran suhu $50-75^{\circ} \mathrm{C}$ (Reiss et al., 2011). Suhu optimum reaksi enzimatik lakase dari Leptographium qinlingensis adalah $45{ }^{\circ} \mathrm{C}(\mathrm{Hu}$ et al., 2014) dan reaksi lakase optimal pada $50{ }^{\circ} \mathrm{C}-60{ }^{\circ} \mathrm{C}$ (Chen et al., 2012). Aktivitas lakase tetap stabil pada $55{ }^{\circ} \mathrm{C}-65^{\circ} \mathrm{C}$ dengan aktivitas relatif $17 \%$ (Asih, 2016).

\section{Refining menggunakan Laccase Mediator System (LMS)}

Pulp hasil pemasakan dikenakan perlakukan dengan LMS yaitu campuran antara lakase

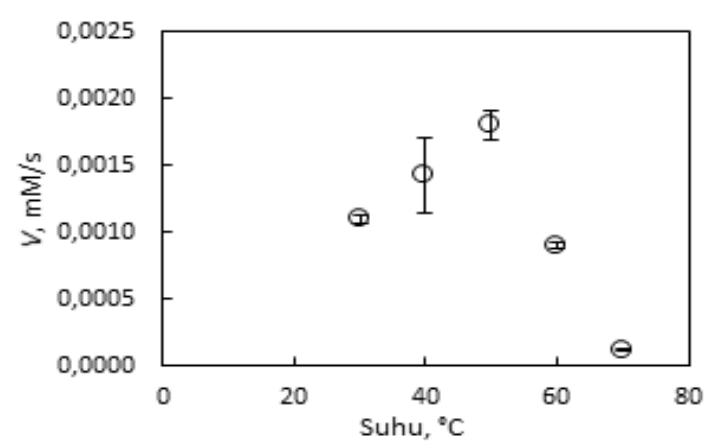

Gambar 7. Suhu Optimum Kecepatan Reaksi Lakase 


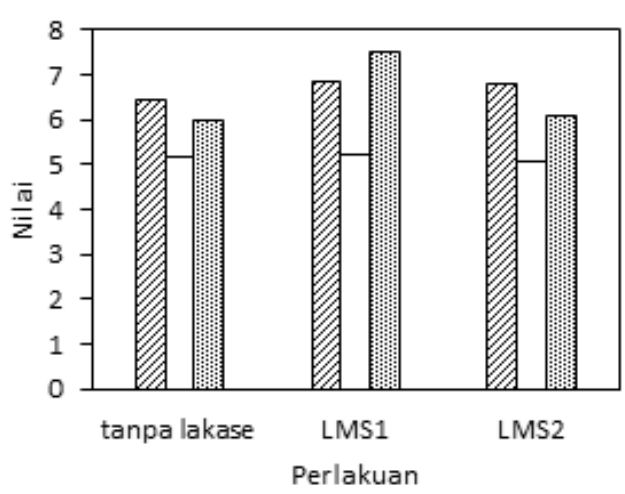

Gambar 8. Kekuatan Lembaran setelah Refining (Tanpa Enzim dan LMS)

$\mathbb{Z}$ Indeks Tarik x $10^{-2}(\mathrm{kNm} / \mathrm{g})$

$\square$ Indeks Retak $\left(\mathrm{kPa} \cdot \mathrm{m}^{2} / \mathrm{g}\right)$

[.: Indeks Sobek $\left(\mathrm{mNm}^{2} / \mathrm{g}\right)$

dengan mediator HBT. Hasil refining dengan PFI mill pada putaran 2.500 antara LMS dan tanpa enzim disajikan pada Gambar 8.

Freeness awal pulp adalah sekitar $550 \mathrm{~mL}$ CSF, dan ketika dikenakan perlakuan lakase turun menjadi 515 (LMS1) dan 520 (LMS2). Pulp tanpa perlakuan enzim menghasilkan indeks tarik, retak dan sobek berturut-turut adalah $6,4 \cdot 10^{-2} \mathrm{kNm} / \mathrm{g}$, $5,18 \mathrm{kPa} \cdot \mathrm{m}^{2} / \mathrm{g}$, dan $5,96 \mathrm{mN} \cdot \mathrm{m}^{2} / \mathrm{g}$. Indeks sobek terlihat tidak mengalami perubahan signifikan pada semua perlakuan. Perlakuan LMS1 meningkatkan indeks tarik menjadi $6,83 \cdot 10^{-2} \quad \mathrm{kNm} / \mathrm{g}$ dan indeks sobek menjadi $7,53 \mathrm{mN} \cdot \mathrm{m}^{2} / \mathrm{g}$. Indeks tarik dan sobek pada LMS2 menurun dibandingkan LMS1, namun masih lebih tinggi dibandingkan tanpa perlakuan. Dengan demikian, perlakuan lakase dapat meningkatkan indeks tarik dan indeks sobek lembaran, yang disebabkan pada saat refining, mampu memperbaiki penyerapan air sehingga meningkatkan swelling dan fleksibilitas serat yang pada akhirnya meningkatkan kekuatan serat. Vishnu Vardhini and Murugan (2016) menyatakan bahwa memodifikasi sifat permukaan dengan menyisihkan lignin. Bila ditinjau dari sisi energi, pada refining 2.500 putaran memerlukan energi sekitar 31-34 Wh untuk semua perlakuan. Perlakuan lakase berpengaruh positif pada sifat kekuatan, sehingga untuk menghasilkan kekuatan yang sama pada freeness yang sama maka perlakuan lakase memerlukan energi yang lebih rendah. Struktur permukaan serat mengalami

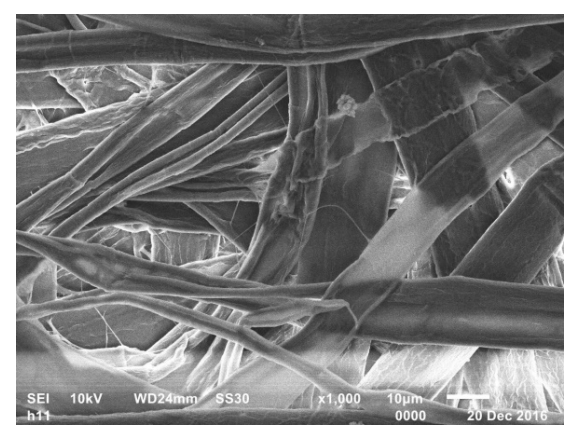

(a) Pulp sebelum Refining

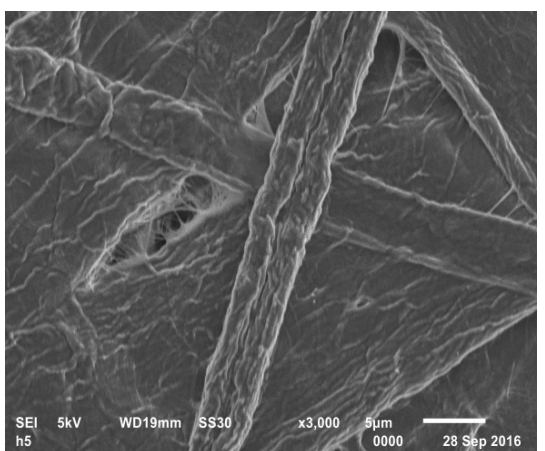

(b) Pulp setelah Refining tanpa Perlakuan Lakase

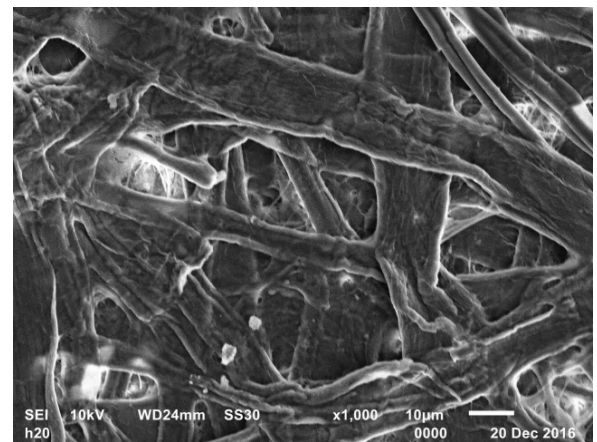

(c) Pulp setelah Refining dengan Perlakuan Lakase

Gambar 9. Struktur Permukaan Pulp selama Perlakuan Refining dan Lakase 
perubahan pada proses perlakuan lakase seperti disajikan pada Gambar 9 (A, B dan C). Terlihat bahwa sebelum refining, pulp masih mulus dan halus, sedangkan setelah refining pulp menjadi pipih dan terbentuk fibril, sedangkan dengan adanya lakase fibril yang terbentuk lebih banyak dibandingkan tanpa perlakuan lakase.

\section{Kesimpulan}

Pada proses refining Acacia crassicarpa menggunakan refiner laboratorium PFI mill menghasilkan putaran optimum untuk PFI mill adalah 2.500 putaran. Suhu optimum untuk proses perlakuan awal lakase adalah $50^{\circ} \mathrm{C}$. Perlakuan Laccase Mediator System (LMS) pada proses refining berpengaruh positif terhadap kekuatan pulp dengan meningkatkan kekuatan tarik dan kekuatan sobek. Refining pulp tanpa perlakuan enzim menghasilkan indeks tarik, retak dan sobek berturut-turut adalah $6,4 \cdot 10^{-2} \mathrm{kNm} / \mathrm{g}, 5,18 \mathrm{kPa} \cdot \mathrm{m}^{2} / \mathrm{g}$, dan $5,96 \mathrm{mN} . \mathrm{m}^{2} / \mathrm{g}$. Indeks sobek tidak mengalami perubahan signifikan pada semua perlakuan. Perlakuan lakase meningkatkan indeks tarik menjadi $6,83.10^{-2} \mathrm{kNm} / \mathrm{g}$ dan indeks sobek menjadi $7,53 \mathrm{mN} \cdot \mathrm{m}^{2} / \mathrm{g}$.

\section{Ucapan Terima Kasih}

Penelitian ini didanai oleh Balai Besar Pulp dan Kertas tahun 2016. Penulis mengucapkan terima kasih kepada tim penelitian di BBPK, Nuralaeli Fidayanti Ahsani dan Mirna Ulfa Fauziah dari UIN Sunan Gunung Djati yang telah membantu pelaksanaan penelitian ini.

\section{Daftar Pustaka}

Abdul-Khalil, H. P. S., Siti Alwani, M. and Mohd Omar, A. K. (2006) 'Chemical composition, anatomy, lignin distribution, and cell wall structure of Malaysian plant waste fibers', BioResources, 1(2), pp. 220 - 232. doi: 10.15376/biores.1.2.220-232.

Asih, S. (2016) Produksi, purifikasi, dan karakterisasi lakase dari Pleurotus ostreatus (Ho) dan Schizophyllum commune (Sc) pada fermentasi padat limbah lignoselulosa. Institut Pertanian Bogor.

Chauhan, V. S., Kumar, N., Kumar, M., Chakrabarti, S. K. and Thapar, S. K. (2011) 'Effect of separate and mixed refining of hardwood and softwood pulps on paper properties', Journal of Korea TAPPI, 43(4), pp. 1-10.
Chen, S. C., Wu, P. H., Su, Y. C., Wen, T. N., Wei, Y. S., Wang, N. C., Hsu, C. A., Wang, A. H. J. and Shyur, L.F.(2012) 'Biochemical characterization of a novel laccase from the basidiomycete fungus Cerrena sp. WR1', Protein Engineering Design and Selection, 25(11), pp. 761-769. doi: 10.1093/protein/gzs082.

Gharehkhani, S., Sadeghinezhad, E., Kazi, S. N., Yarmand, H., Badarudin, A., Safaei, M. R. and Zubir, M. N. M. (2015) 'Basic effects of pulp refining on fiber properties-A review', Carbohydrate Polymers, 115, pp. 785-803. doi: 10.1016/J.CARBPOL.2014.08.047.

Gomes, E., Aguiar, A. P., Carvalho, C. C., Bonfá, M. R. B., Da Silva, R. and Boscolo, M. (2009) 'Ligninases production by basidiomycetes strains on lignocellulosic agricultural residues and their application in the decolorization of synthetic dyes', Brazilian Journal of Microbiology, 40(1), pp. 31-39. doi: 10.1590/S1517-83822009000100005.

Hamidi, N. H. (2013) Enzymatic depolymerization of lignin by laccases.

Hilgers, R., Vincken, J. P., Gruppen, H. and Kabel, M. A. (2018) 'Laccase/Mediator Systems: Their Reactivity toward Phenolic Lignin Structures', ACS Sustainable Chemistry and Engineering. American Chemical Society, 6(2), pp. 2037-2046. doi: 10.1021/ acssuschemeng.7b03451.

Hu, X., Wang, C., Wang, L., Zhang, R. and Chen, H. (2014) 'Influence of temperature, $\mathrm{pH}$ and metal ions on guaiacol oxidation of purified laccase from Leptographium qinlingensis', World Journal of Microbiology and Biotechnology, 30(4), pp. 1285-1290. doi: 10.1007/s11274-013-1554-3.

Iakovlev, M., Hiltunen, E. and Van Heiningen, A. (2010) 'Paper technical potential of spruce $\mathrm{SO}_{2}$-Ethanol-Water (SEW) pulp compared to kraft pulp', Nordic Pulp and Paper Research Journal, 25(4), pp. 428-433. doi: 10.3183/ npprj-2010-25-04-p428-433.

Khakifirooz, A., Ravanbakhsh, F., Samariha, A. and Kiaei, M. (2013) 'Investigating the possibility of chemi-mechanical pulping of bagasse', BioResources, 8(1), pp. 21-30. doi: 10.15376/biores.8.1.21-30.

Kiaei, M. (2014) 'Investigation on biometrical properties and mineral content of rice residues and its application in pulp and paper production', Advances in Environmental Biology, 8(13), pp. 952-959.

Lecourt, M., Soranzo, A. and Petit-Conil, M. (2011) 'Refining of Pine radiata and eucalyptus kraft pulps assisted with commercial laccase mediator systems', $O$ PAPEL, 72(8), pp. 57-61. 
Lian, H. L., You, J. X. and Lian, Z. N. (2012) 'Effect of prior mechanical refining on biobleaching of wheat straw pulp with laccase/xylanase treatment', BioResources, 7(3), pp. 31133124. doi: 10.15376/biores.7.3.3113-3124.

Masrol, S. R., Ibrahim, M. H. I., Adnan, S., Amir Shah, M. S. S., Main, N. M., Esa, M. F. and Othman, M. H. (2015) 'Effect of Beating Process to Soda Anthraquinone Pulp of Oil Palm Male Flower Spikes Fibre', Applied Mechanics and Materials, 773-774, pp. 158-162. doi: 10.4028/www.scientific.net/ amm.773-774.158.

Mossello, A. A., Harun, J., Tahir, P. M., Resalati, H., Ibrahim, R., Fallah Shamsi, S. R. and Mohmamed, A. Z. (2010) 'A Review of Literatures Related of Using Kenaf for Pulp Production (Beating, Fractionation, and Recycled Fiber)', Modern Applied Science, 4(9), pp. 21-29. doi: 10.5539/mas.v4n9p21.

Orwa, C., Mutua, A., Kindt, R., Simons, A. and Jamnadass, R. H. (2009) Agroforestree Database: A Tree Reference and Selection Guide Version 4.0.

Reiss, R. et al. (2011) 'Bacillus pumilus laccase: a heat stable enzyme with a wide substrate spectrum', BMC Biotechnology, 11(1), p. 9. doi: 10.1186/1472-6750-11-9.

Risdianto, H., Sofianti, E., Suhardi, S. H. and Setiadi, T. (2012) 'Optimisation of laccase production using white rot fungi and agriculture wastes in solid state fermentation', ITB Journal of Engineering Science, 44 B(2), pp. 93-105. doi: 10.5614/ itbj.eng.sci.2012.44.2.1.

Rushdan, I. (2003) 'The Effect of Refining on Fibre Morphology and Drainage of Soda Pulp Derived from Oil Palm Empty Fruit Bunches', Journal of Tropical Forest Products, 9(1), pp. 26-34.
Saropah, D. A., Jannah, A. and Maunatin, A. (2012) 'Kinetika Reaksi Enzimatis Ekstrak Kasar Enzim Selulase Bakteri Selulolitik Hasil Isolasi Dari Bekatul', Alchemy, 2(1), pp. 35-45.

Sugesty, S., Kardiansyah, T. and Pratiwi, W. (2015) 'Potensi Acacia crassicarpa sebagai bahan baku pulp kertas untuk hutan tanaman industri', JURNAL SELULOSA. doi: 10.25269/jsel.v5i01.75.

Tavares, A. P. M., Silva, C. G., Dražić, G., Silva, A. M. T., Loureiro, J. M. and Faria, J. L. (2015) 'Laccase immobilization over multi-walled carbon nanotubes: Kinetic, thermodynamic and stability studies', Journal of Colloid and Interface Science, 454, pp. 52-60. doi: 10.1016/j.jcis.2015.04.054.

Udohitinah, J. S. and Oluwadare, A. O. (2011) 'Pulping properties of kraft pulp of Nigeriangrown kenaf (Hibiscus cannabinus L.)', BioResources, 6(1), pp. 751 - 761. doi: 10.15376/biores.6.1.751-761.

Ververis, C., Georghiou, K., Christodoulakis, N., Santas, P. and Santas, R. (2004) 'Fiber dimensions, lignin and cellulose content of various plant materials and their suitability for paper production', Industrial Crops and Products, 19, pp. 245-254. doi: 10.1016/j. indcrop.2003.10.006.

Vishnu Vardhini, K. J. and Murugan, R. (2016) 'Effect of Laccase and Xylanase Enzyme Treatment on Chemical and Mechanical Properties of Banana Fiber', Journal of Natural Fibers, 14(2), pp. 1-11. doi: 10.1080/15440478.2016.1193086. 
Lurnal Selulosa, Vol. 9, No. 2, Desember 2019:65- 74

- Halaman ini sengaja dikosongkan - 